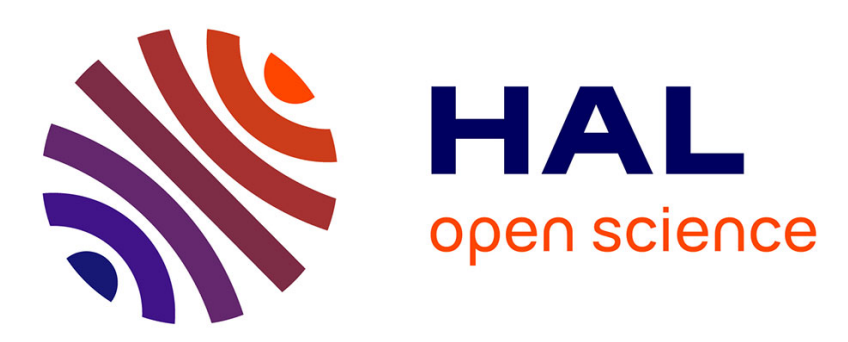

\title{
Revisiting atmospheric dust export to the Southern Hemisphere ocean: Biogeochemical implications
}

Thibaut Wagener, Cécile Guieu, Rémi Losno, Sophie Bonnet, Natalie Mahowald

\section{- To cite this version:}

Thibaut Wagener, Cécile Guieu, Rémi Losno, Sophie Bonnet, Natalie Mahowald. Revisiting atmospheric dust export to the Southern Hemisphere ocean: Biogeochemical implications. Global Biogeochemical Cycles, 2008, 22 (2), pp.n/a-n/a. 10.1029/2007GB002984 . hal-02567410

\section{HAL Id: hal-02567410 \\ https://hal.science/hal-02567410}

Submitted on 9 Apr 2021

HAL is a multi-disciplinary open access archive for the deposit and dissemination of scientific research documents, whether they are published or not. The documents may come from teaching and research institutions in France or abroad, or from public or private research centers.
L'archive ouverte pluridisciplinaire HAL, est destinée au dépôt et à la diffusion de documents scientifiques de niveau recherche, publiés ou non, émanant des établissements d'enseignement et de recherche français ou étrangers, des laboratoires publics ou privés. 


\title{
Revisiting atmospheric dust export to the Southern Hemisphere ocean: Biogeochemical implications
}

\author{
Thibaut Wagener, ${ }^{1,2}$ Cécile Guieu, ${ }^{1,2}$ Rémi Losno, ${ }^{3}$ Sophie Bonnet, ${ }^{4}$ \\ and Natalie Mahowald ${ }^{5}$ \\ Received 28 March 2007; revised 31 October 2007; accepted 12 December 2007; published 22 April 2008.
}

[1] Aerosol concentrations in the Southern Hemisphere are largely undersampled. This study presents a chemical and physical description of dust particles collected on board research vessels in the southeast Pacific (SEPS) and the Southern Ocean (SOKS). Concentrations of dust were $6.1 \pm 2.4 \mathrm{ng} \mathrm{m}^{-3}$ for SEPS and $13.0 \pm 6.3 \mathrm{ng} \mathrm{m}^{-3}$ for SOKS Dust fluxes, derived from those concentrations, were $9.9 \pm 3.7 \mu \mathrm{g} \mathrm{m}^{-2} \mathrm{~d}^{-1}$ for SEPS and $38 \pm 14 \mu \mathrm{g} \mathrm{m}^{-2} \mathrm{~d}^{-1}$ for SOKS and are shown to be representative of actual fluxes in those areas. Dust and iron deposition are up to 2 orders of magnitude lower than former predictions. A map of dust deposition on the Southern Hemisphere is proposed by incorporating those in situ measurements into a dust model. This study confirms that dust deposition is not the dominant source of iron to the large high-nutrient low-chlorophyll Southern Ocean.

Citation: Wagener, T., C. Guieu, R. Losno, S. Bonnet, and N. Mahowald (2008), Revisiting atmospheric dust export to the Southern Hemisphere ocean: Biogeochemical implications, Global Biogeochem. Cycles, 22, GB2006, doi:10.1029/2007GB002984.

\section{Introduction}

[2] Dust, by affecting marine productivity, the radiative budget of Earth, and precipitation patterns, is a significant and recognized factor in forcing global climate [Jickells et $a l ., 2005]$. It has come to be viewed as the main external source of iron for large oceanic areas [Duce and Tindale, 1991; Fung et al., 2000]. Iron limits oceanic productivity in high-nutrient, low-chlorophyll (HNLC) waters [e.g., Martin and Fitzwater, 1988; de Baar et al., 2005; Boyd et al., 2007] and (co)limit nitrogen fixation in some low-nutrient, lowchlorophyll (LNLC) waters [e.g., Mills et al., 2004], thus there has recently been a considerable impetus to understand and estimate dust deposition at the global scale. Dust models [e.g., Luo et al., 2003; Tegen et al., 2002; Ginoux et al., 2004] simulate dust emission, transport, and deposition to calculate dust fluxes on the global scale. Global biogeochemical models have been developed using atmospheric iron derived from those dust models [e.g., Moore et al., 2004; Parekh et al., 2006; Aumont and Bopp, 2006]. To assess the ability of these models in simulating the Earth system, model outputs must be compared against field data.

\footnotetext{
${ }^{1}$ Laboratoire d'Océanographie de Villefranche sur Mer, UMR 7093 CNRS, Villefranche sur mer, France.

${ }^{2}$ Laboratoire d'Océanographie de Villefranche sur Mer, UMR 7093, UPMC Université Pierre et Marie Curie-Paris 6, Villefranche sur mer, France.

${ }^{3}$ Laboratoire Interuniversitaire des Systèmes Atmosphériques, UMR 7583, CNRS, Faculté des Sciences et Technologie, Créteil, France.

${ }^{4}$ IRD, Laboratoire d'Océanographie et de Biogéochimie (L.O.B), Campus de Luminy, Marseille, France.

${ }^{5}$ National Center for Atmospheric Research, Boulder, Colorado, USA.

Copyright 2008 by the American Geophysical Union. 0886-6236/08/2007GB002984
}

However, collecting aerosols over remote oceanic areas remains a difficult task, mainly because of contamination issues upon sampling [Duce, 1989]. In the Southern Hemisphere, dust deposition is much lower than in the Northern Hemisphere because of the scarcity of continental sources [Mahowald et al., 2005]. For open ocean regions in the southern latitudes, only very limited data are available [Jickells and Spokes, 2001; Witt et al., 2006]. Because of their (micro)nutrient limitation, those areas receiving very low atmospheric deposition are likely to respond strongly to changes in atmospheric deposition [Mahowald et al., 2005].

[3] Dust deposition is a highly episodic phenomenon, in particular in areas close to important sources [Jickells and Spokes, 2001]. Prospero et al. [2002], using an extensive study of TOMS images, gives a description of global dust sources. Only three important sources are described for the Southern Hemisphere: (1) Australia is the most important source, essentially the Great Artesian basin, although it is noticeably small compared to the aridity of this continent. (2) In southern Africa two small but persistent sources are described close to $20^{\circ} \mathrm{S}$, one in Botswana and the other one in Namibia. (3) In South America, two distinct source areas are persistent: the Altiplano in the north and Patagonia in the south.

[4] This paper focuses on dust deposition in two distinct remote oceanic areas of the Southern Hemisphere that are unexplored regarding in situ aerosols measurements. (1) The Southern Ocean area was sampled south of Kerguelen Island, between $49^{\circ} \mathrm{S}$ and $54^{\circ} \mathrm{S}$. Atmospheric circulation in this area is characterized by persistent and important winds driving air masses from west to east. (2) The southeast Pacific was sampled over a long longitudinal transect. Although aerosols have been extensively sampled/studied in the Pacific during the SEAREX experiment 

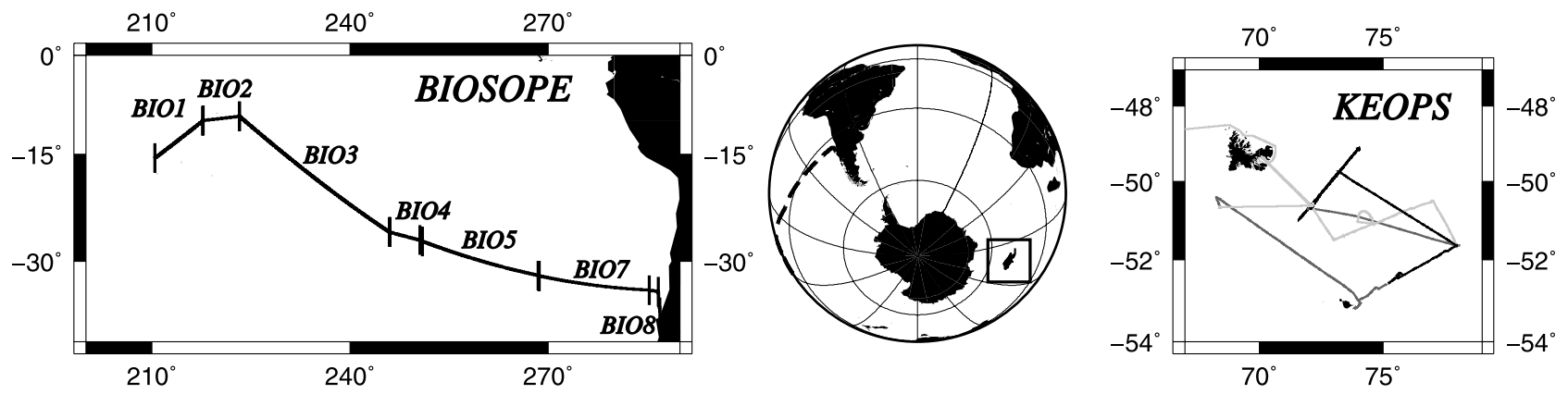

Figure 1. Cruise tracks and location of aerosol sampling.

[Duce, 1989], this large province of the South Pacific Ocean has not been explored so far. The main characteristic for southeast Pacific atmospheric circulation is the presence of a permanent anticyclone. The predominate circulation is the anticyclonic winds around this high-pressure system with subtropical easterly winds north of this area and wind fields lying parallel to the South American coast on the eastern side of the basin [Merrill, 1989]. Both studied areas have atmospheric circulation patterns which would tend to preclude them from receiving continental dust.

[5] The present study aims at (1) describing chemical and physical features of aerosols collected in the southeast Pacific and the Southern Ocean, (2) providing associated dust and iron fluxes, and (3) comparing these fluxes with existing estimations of atmospheric and bottom up iron fluxes within biogeochemical perspectives.

\section{Methods}

\subsection{Sampling}

[6] Aerosol samples were collected during two cruises: (1) The Biogeochemistry and Optics South Pacific Experiment (BIOSOPE) cruise took place along a 8000-km transect through the southeast Pacific from 24 October to 11 December 2004 from Tahiti (French Polynesia) to Concepción (Chile) [Claustre et al., 2008]; during this cruise, seven aerosol samples were collected, labeled from BIO1 to BIO8 (BIO6 missing). (2) The Kerguelen: compared study of the Ocean and the Plateau in Surface water (KEOPS) cruise took place in the Southern Ocean, south of the Kerguelen Island from 10 January to 20 February 2005 [Blain et al., 2007]; during this cruise, six aerosol samples were collected, labeled from $\mathrm{K} 2$ to $\mathrm{K} 7$. Cruise tracks and sampling areas are presented in Figure 1. Details on sampling schedule are provided as auxiliary material ${ }^{1}$ (Table S1).

[7] Aerosols were collected on four separate 47-mmdiameter filters (two $0.4 \mu \mathrm{m}$ porosity polycarbonate, Osmonics, and two Teflon $0.5 \mu \mathrm{m}$, Zefluor, Pall Corporation) at about $1 \mathrm{~m}^{3} \mathrm{~h}^{-1}$ pumping rate. The cumulative amount of pumped air was recorded using volumetric counters. Polycarbonate filters were devoted to particle analyses by transmission electronic microscope (TEM).

${ }^{1}$ Auxiliary materials are available in the HTML. doi:10.1029/ 2007GB002984
Teflon filters were devoted to chemical analysis. They were cleaned by filtering $100 \mathrm{~mL}$ of a $0.2 \mathrm{~mol} \mathrm{~L}^{-1}$ dilution of ultrapure hydrochloric acid (Merck Suprapur grade) in Milli-Q water and then rinsed with $200 \mathrm{~mL}$ of Milli-Q water. Filters were stored in acid-cleaned Petri dishes.

[8] Sampling aerosols on board a research vessel obviates contamination from local lithogenic resuspension. However, the main contamination source for aerosol sampling on a ship (in addition to regular activities on board research vessels) is smoke from the engine exhaust stack. Knowing the low dust levels to be encountered in this study, the samples were protected from this possible contamination by (1) collecting only air masses without any mixing with ship exhausts and (2) protecting the samples when collecting was not possible. To do so, a "box" was designed to achieve an integrative sampling during cruise, together with an efficient protection of the samples during intermediary nonsampling periods. The box was attached on the front deck of the ship to a 7-m-high mast during the BIOSOPE campaign and a 2-m-high mast during the KEOPS campaign. Local wind speed and direction were continuously monitored close to the sampling box using a wind vane/anemometer. Depending on the wind conditions, the sampling box operated either in "protection" or "sampling" mode. "Sampling" mode was defined as the period when air was pumped through the filters to collect aerosols. "Protection" mode was defined as the period when pumping through the filters was stopped and clean filtered air (99.99\%) was blown with a moderate flow (in order to avoid particle removal) over the filter holders. "Sampling" mode was activated only if wind was oriented in a $120^{\circ}$ open angle upwind at a speed higher than $2 \mathrm{~m} \mathrm{~s}^{-1}$. In addition, the "sampling" mode could not be switched from protected mode before a waiting time of $3 \mathrm{~min}$. The device switched into protected mode or reset waiting time immediately if wind conditions were out of the range defined in sampling mode. Wind conditions were averaged above $1 \mathrm{~s}$. In addition, an optical particle counter (MET-ONE 2400) was continuously recording particle concentrations and numbers were averaged over a 1-min period, whatever the sampling mode conditions. The optical particle counter showed no cut in particulate sizes due to aerodynamic effects when comparing distributions in and out of the sampling device. Particle counts demonstrated the efficiency of the sampling device in the protection mode. Furthermore, during both cruises, a "blank" of the sampler 
was determined by placing filters for $3 \mathrm{~d}$ in the collector switched on "protection" mode.

\subsection{Determination of Aluminium Concentration}

[9] A wavelength dispersive X-ray Fluorescence (XRF) spectrometer Phillips PW24004 with a 4kW Rh X-Ray tube was used to perform elemental analyses. XRF is a multielementary method, but only major sea-salt elements and aluminium were above detection limits on the collected samples. Only aluminium $(\mathrm{Al})$ concentrations are presented in this paper. $\mathrm{Al}$ was measured on $\mathrm{K} \alpha$ line using a PE002 crystal, $40 \mathrm{kV}$, and $50 \mathrm{~mA}$ electron excitation beam, an angle of $2 \theta=144.86^{\circ}$ with a background measurement at $-1.08^{\circ}$ offset. Triplicates (each counting duration $=50 \mathrm{~s}$ ) were measured and averaged. Calibration filters were performed by depositing 1,2 , and 3-10 $\mu \mathrm{L}$ drops, respectively, of a $1 \mathrm{~g} \mathrm{~L}^{-1} \mathrm{Al}$ solution stock on a polycarbonate membrane. Once dried, the calibration filters were set at the surface of the same type of Teflon Filters as the ones used for the samples to simulate a thin layer deposit. Direct deposition of solution on the Teflon filters gives no reliable results because of the repulsive interactions between Teflon and water. Thin layer measurement conditions have been assumed for both calibration and sample filters. The area of the X-ray beam was smaller than the deposition area of the samples, and the deposition area was different between samples and standards. Therefore a geometric correction had to be performed. The geometric correction factor was inferred from an intercalibration correlation on major seasalt elements $(\mathrm{Na}, \mathrm{Ca}$, and $\mathrm{Mg}$ ) between XRF measurements and inductively coupled plasma-atomic emission spectrometer (after acid digestion) measurements. The detection limit for the $\mathrm{Al}$ analyses was determined by blank dispersion and found to be $5 \mathrm{ng}$ per filter. The relative uncertainty on sample measurements was circa $16 \%$.

\subsection{Particle Description and Size Distribution}

[10] The aim of microscopic observations was to describe the collected particles and determine their size distribution, in particular for dust. A transmission electronic microscope (JEOL 100CXII) coupled with a microanalyzer (PGT, dispersion spectrometry of X-Ray Energy, EDX) was used following these analytical conditions: accelerating voltage $=$ $100 \mathrm{kV}$, tilt angle in the direction of detector $=35^{\circ}$, accumulation time $=60-200 \mathrm{~s}$, and focused beam size $=$ $0.3 \mu \mathrm{m}$. The filters were prepared following a protocol adapted from Gaudichet et al. [1986]. One-eighth of the sample was cut with a new and clean scalpel. This piece of filter was coated with a carbon layer and directly transferred onto a copper electron microscope grid (diameter: $3.05 \mathrm{~mm}$, 200 mesh of $6400 \mu \mathrm{m}^{2}$ each) by dissolving the filter substrate under suction with chloroform. For each grid, 15 squares were observed randomly with TEM. Particles were identified, counted, and analyzed to identify the lithogenic particles. Because of the extremely low numbers of particles detected (often less than five on each sample), observations have been extended to several samples by pooling together the available data. The TEM observations of samples $\mathrm{BIO} 1$ to $\mathrm{BIO} 7$ were merged together as a representative observation of the southeast Pacific called southeast Pacific sample (SEPS), and the observations of all the samples of the KEOPS cruise were merged together as a representative observation of the Southern Ocean called Southern Ocean-Kerguelen sample (SOKS).

\subsection{Other Supporting Data}

\subsubsection{Ozone Monitoring Instrument Data}

[11] The absorbing aerosol index (A.I.) of the ozone monitoring instrument (OMI) was used as a tool to assess atmospheric dust variability over both sampled areas, in order to better understand how representative the concentration data taken during this cruise was for the seasonal average. A.I. positive values measure absorbing aerosols, such as dust and smoke particles [Herman et al., 1997; Prospero et al., 2002; Ginoux and Torres, 2003]. Inherent problems to the A.I. have been described for the detection of high-latitude or low-altitude aerosols [Herman et al., 1997], which may particularly be a problem for the KEOPS area.

[12] A.I. values were extracted for each daily gridded data (L3-(NASA/GSFC, Ozone Processing Team, available at http://jwocky.gsfc.nasa.gov/)) during the cruise periods for the corresponding areas $\left(150^{\circ} \mathrm{W} / 73^{\circ} \mathrm{W} / 37.5^{\circ} \mathrm{S} / 8.5^{\circ} \mathrm{S}\right.$ for SEPS and $68.125^{\circ} \mathrm{E} / 78.125^{\circ} \mathrm{E} / 53.5^{\circ} \mathrm{S} / 48.5^{\circ} \mathrm{S}$ for SOKS). The A.I. for both investigated areas and period was compared with the complete set of data available from the OMI instrument (September 2004 to September 2006). For SOKS, because of its high-latitude location, wintertime values (April to September) have been eliminated from this study because of probable subpixel cloud problems.

\subsubsection{Air Mass Back Trajectories}

[13] Air mass trajectories are commonly used by atmospheric chemists as an approach to determine the potential origin of sampled aerosols. Here, air mass back trajectories have been calculated using the Hybrid Single Particle Lagrangian Integrated trajectory from the NOAA Air Resource Laboratory (HYSPLIT) model [Draxler and Rolph, 2003] with reanalyzed archived meteorological data (FNL).

[14] Trajectories were calculated at four different heights within the atmospheric boundary layer $(10,100,500$, and $1000 \mathrm{~m}$ ) up to $120 \mathrm{~h}$ back. The trajectory at $10 \mathrm{~m}$ was representative of the air at the sampling height during the cruise. The heights of 1000 and $500 \mathrm{~m}$ were approximations of the upper limits of the marine boundary layer during the day and at night respectively [Witt et al., 2006]. For SOKS, every $24 \mathrm{~h}$ from 10 January 2005 to 20 February 2005, a trajectory was calculated with a finishing point in the center of the area $\left(51.5^{\circ} \mathrm{S}\right.$ to $\left.73^{\circ} \mathrm{E}\right)$. For SEPS cruise (which took place over a broader area), for each sampling day, a trajectory was calculated with a finishing point at the position of the ship at $12 \mathrm{~h}$ UTC.

[15] Moreover, from September 2004 to August 2006, trajectories were calculated up to $240 \mathrm{~h}$ back every $24 \mathrm{~h}$ for two finishing points at $100 \mathrm{~m}$ : (1) in the middle of SOKS area $\left(51.5^{\circ} \mathrm{S}\right.$ to $\left.73^{\circ} \mathrm{E}\right)$ and (2) in the middle of SEPS area $\left(27^{\circ} \mathrm{S}\right.$ to $\left.263^{\circ} \mathrm{E}\right)$. Three simplified dust source areas were defined: Australia (between $-15^{\circ} \mathrm{N} /-35^{\circ} \mathrm{N}$ and $150^{\circ} \mathrm{E} /$ $130^{\circ} \mathrm{E}$ ), South America (between $-20^{\circ} \mathrm{N} /-55^{\circ} \mathrm{N}$ and $-55^{\circ} \mathrm{E} /-72^{\circ} \mathrm{E}$ ), and South Africa (between $-15^{\circ} \mathrm{N} /-27^{\circ} \mathrm{N}$ and $\left.15^{\circ} \mathrm{E} / 30^{\circ} \mathrm{E}\right)$. The frequency of trajectories crossing 
Table 1. Aluminium Concentrations in the Collected Aerosols for Both Cruises

\begin{tabular}{|c|c|c|c|}
\hline \multicolumn{2}{|c|}{$\begin{array}{l}\text { Southeast Pacific } \\
\text { (BIOSOPE-SEPS) }\end{array}$} & \multicolumn{2}{|c|}{$\begin{array}{l}\text { Southern Ocean } \\
\text { (KEOPS-SOKS) }\end{array}$} \\
\hline Sample & $\begin{array}{l}\text { Al Concentration, } \\
\mathrm{ng} \mathrm{m}^{-3}\end{array}$ & Sample & Al Concentration \\
\hline BIO1 & $0.30 \pm 0.05$ & K 2 & $1.23 \pm 0.19$ \\
\hline $\mathrm{BIO} 2$ & $0.40 \pm 0.06$ & K 3 & $1.75 \pm 0.23$ \\
\hline $\mathrm{BIO} 3$ & $0.83 \pm 0.12$ & K 4 & $0.59 \pm 0.09$ \\
\hline BIO4 & $0.45 \pm 0.07$ & K 5 & $0.50 \pm 0.08$ \\
\hline BIO5 & $0.47 \pm 0.07$ & K 6 & $1.23 \pm 0.19$ \\
\hline BIO7 & $0.37 \pm 0.06$ & K 7 & $0.68 \pm 0.10$ \\
\hline $\mathrm{BIO} 8$ & $19.0 \pm 3.0$ & & \\
\hline $\begin{array}{l}\text { Mean (BIO1-BIO7) } \\
\quad \pm \text { SD }\end{array}$ & $0.47 \pm 0.19$ & Mean \pm SD & $1.00 \pm 0.49$ \\
\hline
\end{tabular}

these three areas was determined at 24-h intervals. It has to be noted that the error on trajectory determination is increasing at each step of the calculation, and thus the error on 10-d trajectories might be important. Nevertheless, they could still give an indication on preferential dust sources to the sampled areas.

\subsubsection{Dust Model Data}

[16] Dust model outputs from the model described in detail by Mahowald et al. [2002], Luo et al. [2003], and Mahowald et al. [2003] were used for this study. The dust entrainment and deposition were simulated for four size bins following the Dust Entrainment and Deposition module [Zender et al., 2003]. Transport was simulated by the Model of Atmospheric Transport and Chemistry (MATCH) [Mahowald et al., 1997] using National Center for Environmental Prediction/National Center for Atmospheric Research winds, which are a combination of model and observations [Kistler et al., 2001]. Some systematic discrepancies have been pointed out for this data set in the Southern Hemisphere [Dell' Aquila et al., 2007]. The ability of the model to capture the climatology of dust was examined in detail by Luo et al. [2003], and the interannual and daily variability was examined by Mahowald et al. [2003], Hand et al. [2004], and Luo et al. [2005]. The exact same model set up and simulations were extended from those studies into 2005 for comparison to the observations of this paper for the correct days and years. References to the results of the model are referred hereafter as Luo model (Lm).

[17] Data from global Lm were extracted for our studied areas as follows: (1) for the SEPS area, Lm values were averaged over all pixels corresponding spatially and temporally to the cruise track and (2) for the SOKS area, Lm values were averaged from $49^{\circ} \mathrm{S} / 68^{\circ} \mathrm{W}$ to $54^{\circ} \mathrm{S} / 78^{\circ} \mathrm{W}$ for the months of January and February. For dust concentrations, values were averaged in the first atmospheric layer of the model for the months of the cruises (pressure value: $995 \mathrm{hPa}$, which corresponds to surface concentration). For dust deposition, climatological values from Lm and from a composite of three dust models [Mahowald et al., 2005] were used.

[18] In order to provide a new estimate of dust deposition to the open ocean of the Southern Hemisphere, we com- bined our data with Lm output. Simulations were conducted for the period from March 2004 to March 2005 (with the first month used for spin up) only with the Southern Hemisphere sources (Australia, South Africa, and South America). The minimum of difference between the in situ concentration and the average of the model surface concentration (for SOKS and SEPS) has been optimized using a cost function in order to obtain a correction factor for each source.

\section{Results}

\subsection{Aluminium Concentrations}

[19] Al concentrations for all collected samples are reported in Table 1. Close to the Chilean coast, Al concentration was 40 times higher than elsewhere in the study region. This value is significantly different from the other concentration values ( $\mathrm{t}$ test, $\alpha=0.05, v=7$ ). The variability (assessed here by the Coefficient of variation, $\mathrm{CV}$ ) was low between $\mathrm{BIO} 1$ to $\mathrm{BIO} 7(\mathrm{CV}=40 \%)$ with regard to the broad area it represents. For KEOPS, the variability between samples was higher $(\mathrm{CV}=47 \%)$. However, for both areas the variability was low enough to allow to pool together the observations of TEM. Globally, Al concentrations were not significantly different between SEPS (BIO8 not included) and SOKS areas (t test, $\alpha=0.05, v=12$ ). Al was under detection limit of the XRF method for the blank filters collected on both cruises.

\subsection{TEM Observations and Grain Size Distribution of Dust}

[20] For all samples (BIO8 not included), only three types of particles were observed by TEM: (1) the major part of all collected material was "sea-salt" particles, (2) then calcium sulphate (presumably Gypsum), known to originate from marine sources [Andreae et al., 1986], and (3) silicate particles, typical of terrigenous sources, which represented less than $0.1 \%$ of the observed particles. Internal mixing of silicate particles with sea salt was observed (Figure 2). Microscopic analysis coupled to microanalysis showed that silicate particles (i.e., dust) contained iron and aluminium (Figure 2). They were the only particles able to transport iron over those remote oceanic areas. No particles were observed with TEM on the "blank" filters.

[21] Mass size distribution (MSD) for SEPS and SOKS are reported in Figure 3. A monomodal integrated normal distribution was used to fit the data following the method from Dulac et al. [1989]. The mass median diameters (MMD) and the geometric standard deviation $(\sigma)$ were $2.20 \mu \mathrm{m}\left(\sigma_{\text {SEPS }}: 1.36\right)$ for SEPS and $2.27 \mu \mathrm{m}\left(\sigma_{\text {SOKS }}\right.$ : 1.54) for SOKS. Both distributions were not significantly different ( $\mathrm{t}$ test, $\alpha=0.05, v=39$ ).

\subsection{Estimated Dust Concentrations and Fluxes}

[22] Dust concentrations (Table 2) were calculated by two independent methods: (1) Al concentration measured by XRF on each aerosol sample was averaged for each cruise; by assuming that $\mathrm{Al}$ is only transported by dust (supported by TEM observations) and represents $7.7 \%$ in mass of terrigeneous particles [Wedepohl, 1995], a dust concentra- 


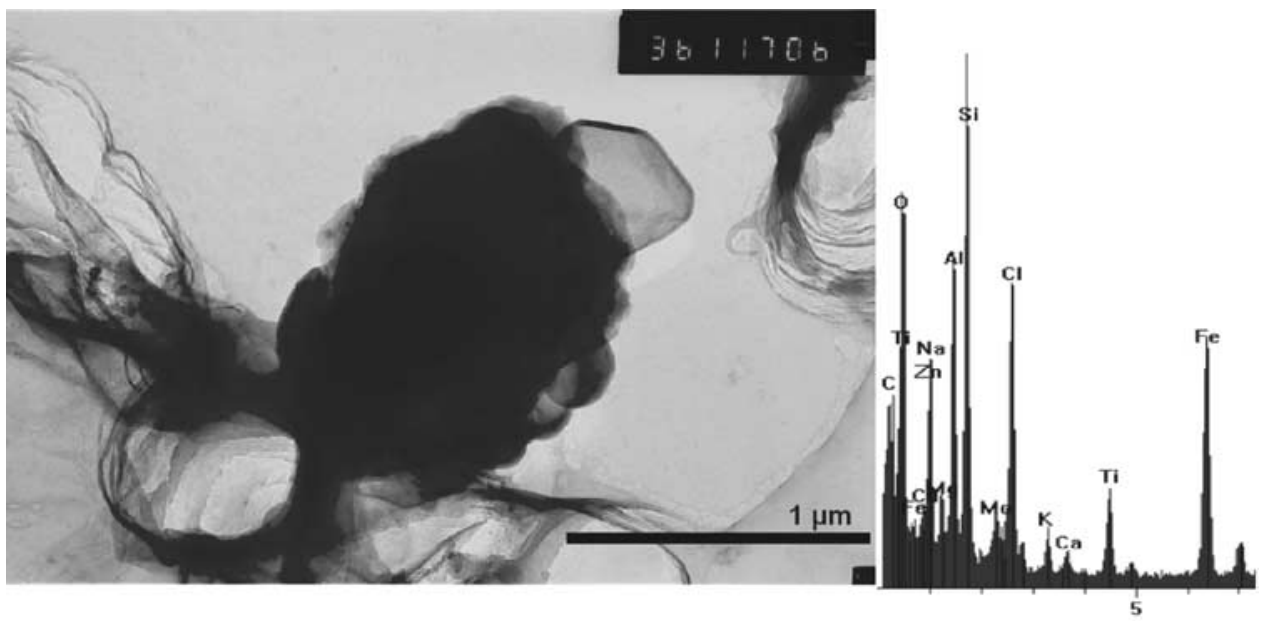

Figure 2. Electron Microphotograph and EDX spectra of a silicate particle internally mixed with sea salt collected on sample BIO2 during the BIOSOPE cruise. The EDX spectra correspond to a measurement with the beam focused on the border of the silicate particle.

tion was calculated. (2) The size and number of particles transporting iron were determined by TEM observations on a fraction of filter, and those numbers were then extrapolated to the whole filter; by assuming that dust particles had a shape between half-spherical and spherical [Ezat and Dulac, 1995] and a density of $2300 \pm 300 \mathrm{~kg} \mathrm{~m}^{-3}$, a dust concentration was calculated. By using method 1, dust concentrations were $6.1 \pm 2.4 \mathrm{ng} \mathrm{m}^{-3}$ for SEPS and $13.0 \pm$ $6.3 \mathrm{ng} \mathrm{m}^{-3}$ for SOKS. By using method 2, dust concentrations were between 3.2 and $7.4 \mathrm{ng} \mathrm{m}^{-3}$ for SEPS and between 6.9 and $15.4 \mathrm{ng} \mathrm{m}^{-3}$ for SOKS.
[23] Though only Al concentrations are presented in this manuscript, XRF analysis have clearly pointed out the dominance $(>99 \%)$ of elements from sea-salt origin on the collected aerosol. Al from sea-salt origin (calculated with a $\mathrm{Al} / \mathrm{Na}$ ratio in seawater of $9.10^{-8}: \mathrm{Na}$ and $\mathrm{Ca}$ concentrations are provided as auxiliary material (Table S2)) represents less than $0.2 \%$ of total $\mathrm{Al}$ on the filters. This large dominance of sea-salt particles is also supported by TEM observations. However, the estimated dust concentrations from a very small number of particles (less than $0.1 \%$ of the observed particles) are reliable because the same numbers were obtained from

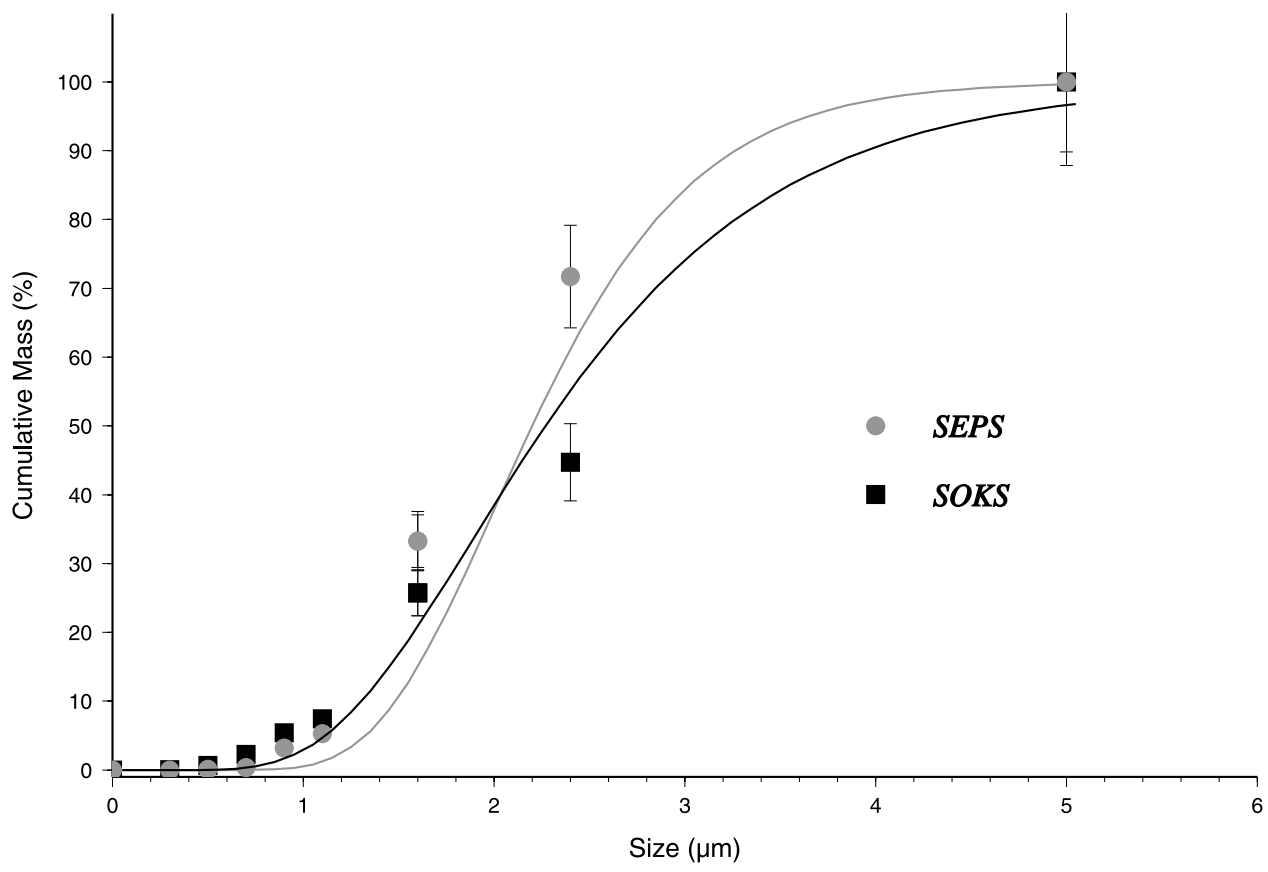

Figure 3. Cumulated mass size class distribution by transmission electronic microscope (TEM) for both cruises. Error bars represent the square root of the number of counted particles in each size class. 
Table 2. Concentrations of Dust Determined in This Study Compared to Literature Values

\begin{tabular}{|c|c|c|c|c|c|}
\hline & (Th & $\begin{array}{l}\text { Situ } \\
\text { Study), } \\
\mathrm{m}^{-3}\end{array}$ & $\begin{array}{c}\text { In Situ } \\
\text { (Literature), } \\
\text { ng m }^{-3}\end{array}$ & & $\begin{array}{l}\text { Model } \\
(\mathrm{Lm})^{\mathrm{f}} \\
\mathrm{ng} \mathrm{m}^{-3}\end{array}$ \\
\hline SEPS & $\begin{array}{l}\text { From } \\
\text { FX }^{\mathrm{a}}\end{array}$ & $6.1 \pm 2.4$ & American $\mathrm{Samoa}^{\mathrm{c}}$ & 20 & $340 \pm 203$ \\
\hline \multirow{3}{*}{ SOKS } & TEM $^{\mathrm{b}}$ & $3.2-7.4$ & Raratonga $^{c}$ & 110 & \\
\hline & $\begin{array}{l}\text { From } \\
\text { FX }^{\mathrm{a}}\end{array}$ & $13.0 \pm 6.3$ & Amsterdam Island $^{\mathrm{d}}$ & 120 & $156 \pm 23$ \\
\hline & $\begin{array}{l}\text { From } \\
\text { TEM }^{\mathrm{b}}\end{array}$ & $6.9-15.4$ & Antarctic penninsula ${ }^{\mathrm{e}}$ & 2 & \\
\hline
\end{tabular}

${ }^{a}$ Values assessed with mean aluminium concentration determined by XRF (see section 2).

${ }^{\mathrm{b}}$ Values assessed with transmission electronic microscope (TEM) observations (see section 2).

${ }^{\mathrm{c}}$ [Prospero et al., 1989].

[Ezat and Dulac, 1995].

' $[$ Dick, 1991].

Values from Lm (see section 2.4.3).

two independent methods. Such determinations were possible because of the use of this sampling device which excluded local ship contamination and therefore allowed a confidence in the observed particles by TEM.

[24] Dust fluxes were calculated by summing the dry and wet deposition. Dry deposition was calculated by considering the actual dust concentrations determined by method 1 and a deposition velocity following the 100-step method proposed by [Dulac et al., 1989]. This calculation is based on Slinn and Slinn [1980] deposition model and takes into account the size dispersion of the particles. The mean wind speed used for both cruises was determined from onboard meteorological measurements (BIOSOPE: $6 \mathrm{~m} \mathrm{~s}^{-1}$; KEOPS: $12 \mathrm{~m} \mathrm{~s}^{-1}$ ).

[25] Scavenging ratios $\left(\mathrm{SR} ; \mathrm{SR}=\mathrm{C}^{\text {precipitation }} /\left(\mathrm{C}^{\text {aerosol }} \times\right.\right.$ $\left.\rho^{\text {air }}\right)$ ) combined to monthly mean precipitation values [Global Precipitation Climatology Project (GPCP), 2000; Adler et $a l ., 2003]$ were used to estimate wet deposition. Two scavenging ratios were considered: a $\mathrm{SR}=200$ which has been suggested to be typical of oceanic atmosphere [Jickells and
Spokes, 2001] and is in good agreement with field data of SR obtained on Pacific Islands [Buat-Menard and Duce, 1986] and a SR $=750$ which is currently used in dust models [Luo et al., 2003; Tegen et al., 2002]. For precipitation, monthly mean values at the time of both cruises (GPCP, 2000) (SEPS: $2.1 \pm 1.8 \mathrm{~mm} \mathrm{~d}^{-1}$; SOKS: $3.1 \pm$ $0.3 \mathrm{~mm} \mathrm{~d}^{-1}$ ) were used. Dry and total fluxes are reported in Table 3. Iron fluxes, inferred from those numbers by assuming a $3.5 \%$ mass concentration of iron in dust [Jickells and Spokes, 2001], are also shown. Studies have suggested that iron amounts in dust do not vary more than a factor of 50\% [Mahowald et al., 2005].

\subsection{Other Measurements Support \\ 3.4.1. OMI Aerosol Index}

[26] The daily A.I. given by the Ozone Mapping Instrument (OMI) (NASA/GSFC, Ozone Processing Team, available at http://jwocky.gsfc.nasa.gov/) during the cruises was $0.327 \pm 0.075(\mathrm{n}=35)$ for SEPS and $0.154 \pm 0.080(\mathrm{n}=38)$ for SOKS. Those numbers were not significantly different than the mean of available A.I. data from September 2004 to September 2006 presented in Figure 4. No particular "dust event" (A.I. > 0.7) could be identified during both cruises.

\subsubsection{Back Trajectories}

[27] Back trajectories at 100-m altitude for both cruises are reported in Figure 5. Only 100-m trajectories are shown as no striking differences were observed between the 10-, 100-, 500-, and 1000-m trajectories. For the KEOPS area, the general east to west circulation is clearly seen (Figure 5a). In the northwestern part of the BIOSOPE area, air masses blowing westward are evident, while in the central part, trajectories are turning around the anticyclone without crossing any continental source; finally, in the southeastern region, close to the Chilean coast, south-north trends are clearly seen (Figure $5 \mathrm{~b}$ ). Only for the last sample (BIO8), trajectories are originating from the South America peninsula (Figure 5b). Frequency of trajectories crossing dust source areas are given in Table 4. For SOKS area, this frequency is extremely low (less than $2 \%$ ). For SEPS area,

Table 3. Estimated Dust Fluxes Over Both Areas

\begin{tabular}{|c|c|c|c|c|}
\hline & Dust, $\mu \mathrm{g} \mathrm{m}^{-2} \mathrm{~d}^{-1}$ & Iron, $\mathrm{nmol} \mathrm{m}^{-2} \mathrm{~d}^{-1}$ & Dust, $\mu \mathrm{g} \mathrm{m}^{-2} \mathrm{~d}^{-1}$ & Iron, $\mathrm{nmol} \mathrm{m} \mathrm{m}^{-2} \mathrm{~d}^{-1}$ \\
\hline Area & BIOSOPE - SEPS & BIOSOPE - SEPS & KEOPS - SOKS & KEOPS - SOKS \\
\hline Longitude & $150-75^{\circ} \mathrm{W}$ & $150-75^{\circ} \mathrm{W}$ & $68-78^{\circ} \mathrm{E}$ & $68-78^{\circ} \mathrm{E}$ \\
\hline Latitude & $8-36^{\circ} \mathrm{S}$ & $8-36^{\circ} \mathrm{S}$ & $49-54^{\circ} \mathrm{S}$ & $49-54^{\circ} \mathrm{S}$ \\
\hline Flux "Dry"a & $7.7 \pm 2.6$ & $4.8 \pm 1.6$ & $31 \pm 11$ & $19 \pm 7$ \\
\hline $\begin{array}{l}\text { Flux "Dry + Wet" } \\
\quad(\mathrm{SR}=200)^{\mathrm{b}}\end{array}$ & $9.9 \pm 3.7$ & $6.2 \pm 2.3$ & $38 \pm 14$ & $23 \pm 9$ \\
\hline $\begin{array}{l}\text { Flux "Dry + Wet" } \\
\quad(\mathrm{SR}=750)^{\mathrm{c}}\end{array}$ & $16.1 \pm 4.2$ & $10.1 \pm 2.9$ & $56 \pm 16$ & $35 \pm 12$ \\
\hline Flux $\operatorname{Lm}^{\mathrm{d}}$ & $334 \pm 129$ & $209 \pm 81$ & $410 \pm 46$ & $257 \pm 29$ \\
\hline Flux model Mahowald & $411 \pm 246$ & $258 \pm 154$ & $296 \pm 55$ & $185 \pm 34$ \\
\hline Flux Duce $\mathrm{e}^{\mathrm{f}}$ & $27-270$ & $17-170$ & $27-270$ & $17-170$ \\
\hline \multicolumn{5}{|c|}{$\begin{array}{l}\text { a Determined by the Dulac et al. [1989] method (see text). } \\
\text { bDry + wet determined with a scavenging ratio of } 200 . \\
\text { cDry + wet determined with a scavenging ratio of } 750 . \\
\text { d Values from Lm (see section 2.4.3). } \\
\text { 'Values from model composite [Mahowald et al., } 2005] \text { (see section 2.4.3). } \\
{ }^{\text {f } V a l u e s ~ f r o m ~ e x t r a p o l a t i o n ~ o f ~ i n ~ s i t u ~ v a l u e s ~ f r o m ~ D u c e ~ e t ~ a l . ~[1991] . ~ T h e ~ v a l u e s ' ~ r a n g e ~ w e r e ~ v i s u a l l y ~ d e t e r m i n e d ~ f r o m ~ t h e ~}\end{array}$} \\
\hline
\end{tabular}




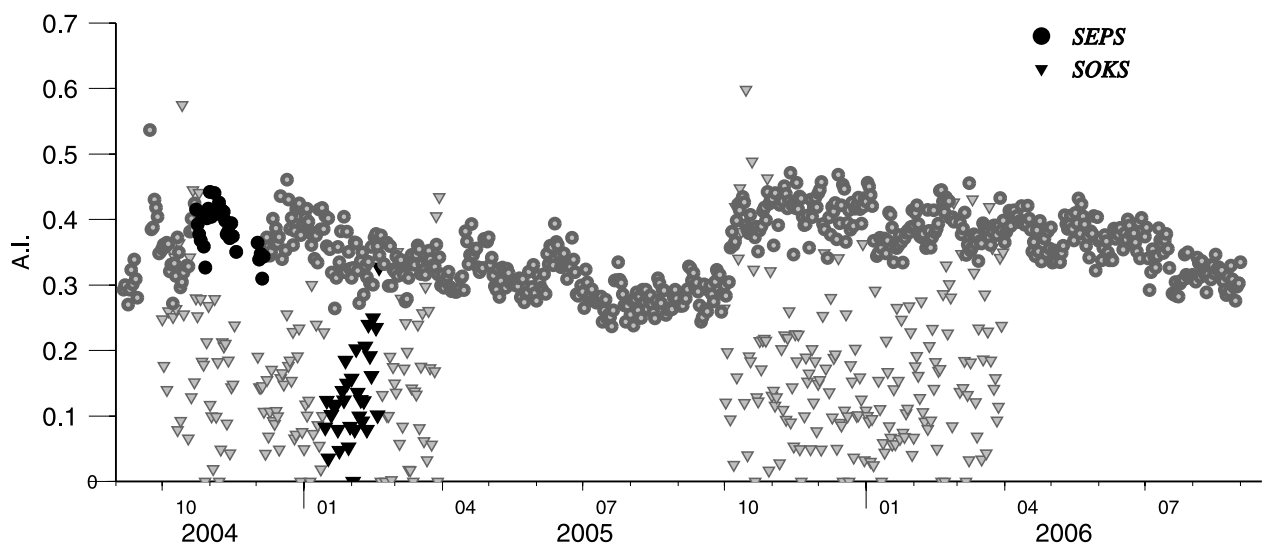

Figure 4. Daily Mean Aerosol Index from the OMI instrument over the SEPS and SOKS area. Values corresponding to the period of both cruises are in black.
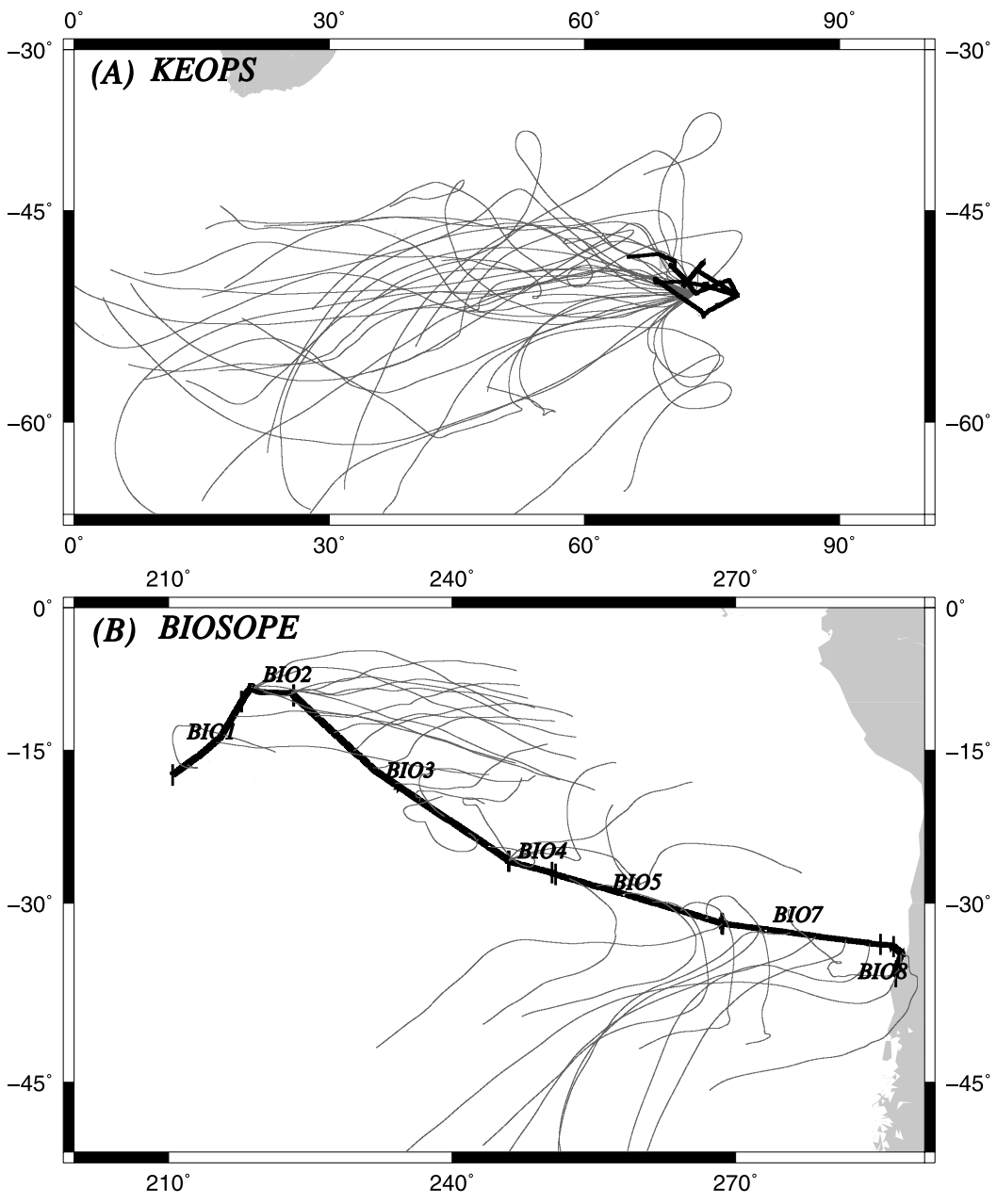

Figure 5. Air mass back trajectories calculated from the HYSPLIT model. (a) Trajectories finishing on a point centered in the middle of the KEOPS area $\left(51.5^{\circ} \mathrm{S}\right.$ to $\left.73^{\circ} \mathrm{E}\right)$. (b) Trajectories finishing on a point at the position of the ship at $12 \mathrm{~h}$ UTC during sampling on the BIOSOPE cruise. 
Table 4. Frequency of Back Trajectories Crossing With Sources in Percent up to $240 \mathrm{~h}$ Back Between 1 September 2004 and 31 August $2006(\mathrm{n}=730)$

\begin{tabular}{|c|c|c|c|c|c|c|}
\hline \multirow{2}{*}{$\begin{array}{c}\text { Time Back, } \\
\text { hours }\end{array}$} & \multicolumn{3}{|c|}{ BIOSOPE - SEPS ${ }^{\mathrm{a}}$} & \multicolumn{3}{|c|}{ KEOPS - SOKS $^{b}$} \\
\hline & $\mathrm{AUS}^{\mathrm{c}}$ & $\mathrm{SAM}^{\mathrm{d}}$ & $\mathrm{SAF}^{\mathrm{e}}$ & $\mathrm{AUS}^{\mathrm{c}}$ & $\mathrm{SAM}^{\mathrm{d}}$ & $\mathrm{SAF}^{\mathrm{e}}$ \\
\hline-24 & 0 & 0 & 0 & 0 & 0 & 0 \\
\hline-48 & 0 & 0 & 0 & 0 & 0 & 0 \\
\hline-72 & 0 & 0 & 0 & 0 & 0 & 0 \\
\hline-96 & 0 & 0 & 0 & 0 & 0 & 0 \\
\hline-120 & 0 & 0 & 0 & 0 & 0 & 0 \\
\hline-144 & 0 & 0 & 0 & 0 & 0.41 & 0 \\
\hline-168 & 0 & 0 & 0 & 0.41 & 0.41 & 0 \\
\hline-192 & 0 & 0 & 0 & 0.55 & 0.96 & 0 \\
\hline-216 & 0 & 0 & 0 & 1.10 & 1.37 & 0 \\
\hline-240 & 0 & 0 & 0 & 1.10 & 1.92 & 0 \\
\hline
\end{tabular}

${ }^{a}$ Back trajectories for an ending point in the middle of SEPS area $\left(-27^{\circ} \mathrm{N} /-107^{\circ} \mathrm{E}\right)$.

${ }^{\mathrm{b}}$ Back trajectories for an ending point in the middle of SOKS area $\left(-51^{\circ} \mathrm{N} / 73^{\circ} \mathrm{E}\right)$.

${ }^{\mathrm{c}}$ Area of Australian sources defined between $-15^{\circ} \mathrm{N} /-35^{\circ} \mathrm{N}$ and $150^{\circ} \mathrm{E} /$ $130^{\circ} \mathrm{E}$

${ }^{\mathrm{d}}$ Area of South American sources defined between $-20^{\circ} \mathrm{N} /-55^{\circ} \mathrm{N}$ and $-55^{\circ} \mathrm{E} /-72^{\circ} \mathrm{E}$.

${ }^{\mathrm{e}}$ Area of South African sources defined between $-15^{\circ} \mathrm{N} /-27^{\circ} \mathrm{N}$ and $15^{\circ} \mathrm{E} / 30^{\circ} \mathrm{E}$.

no 10 -d trajectory is crossing a continental dust source during the 2 years studied.

\section{Discussion}

4.1. Dust Over Remote Oceanic Areas of the Southern Hemisphere

[28] Mass size distributions of collected dust particles (Figure 3) show smaller median mass diameters (MMD) compared to other MMD representative of long-range transported dust particles reported in the literature [see, e.g., Maring et al., 2003; Ezat and Dulac, 1995]. According to Tanaka and Chiba [2006], we assume that the Australian desert is the main source of dust for SEPS and the South American desert is the main source for SOKS. Although the source is more distant in the case of SOKS than in the case of SEPS, the grain size distributions of silicates particles collected in both areas are not significantly different. Maring et al. [2003] suggested that, over long-range transport, distance does not significantly play on the size distribution of small mode particles. The MMD reported in this study are the lowest ever reported but, to our knowledge, no study has pointed out a particularly narrow range in the production of dust particles from Southern Hemisphere sources. Therefore, removal of part of smallmode particles over long-range transport cannot be excluded in this study. Although large particles $(>10 \mu \mathrm{m})$ can be transported over long distances in the North Pacific Ocean [Betzer et al., 1988], none such particles are found in our samples. A plausible explanation is the combination of the paucity of significant sources of particles in the Southern Hemisphere and unfavorable atmospheric circulation for transport to the studied areas.

[29] No noticeable increase in $\mathrm{Al}$ (and dust) is found closer to the Kerguelen Island suggesting that, at least during the KEOPS cruise, the Kerguelen "desert" [as defined by Dulac et al., 2006] is not a significant source of particles for the downwind area. In the southeast Pacific, Al concentrations are rather constant over the whole longitudinal section up to $250 \mathrm{~km}$ from the Chilean coast, where an obvious continental imprint is detected. These observations are in agreement with the general atmospheric circulation in that area that precludes the South American continent to be a source of particles to the southeast Pacific. The dust concentrations determined for both areas are in the lowest range among data from the literature (Table 2). The SEPS values are 3 to 20 times lower than dust concentrations determined during the SEAREX experiment on American Samoa and Raratonga Islands (see references in Table 2). Both measurement sites are located west of the SEPS zone and are obviously under a higher influence of the Australian continent. In the Southern Ocean, a clear decreasing latitudinal trend in dust concentrations can be seen as SOKS value is 10 times smaller than levels observed on the Amsterdam Island (situated $15^{\circ}$ farther north), but 7 times higher than dust concentration measured on the Antarctic peninsula (see references in Table 2). The dust model $(\mathrm{Lm})$ overestimates concentration values encountered in both studied areas by a factor of 10-50 (Table 2).

[30] The extremely low dust concentrations presented in this study are in good agreement with the back trajectories calculated. Indeed, the latter demonstrates that the sampled air masses were not prone to enrichment by lithogenic dust as they did not cross a continental area at least during the $5 \mathrm{~d}$ preceding the collection. Moreover, the study of back trajectories over 2 years shows that for both sampled areas the frequency of air masses which have crossed a dust source area within $10 \mathrm{~d}$ is extremely low, suggesting that both areas receive dust which has been transported over long distances and for more than $10 \mathrm{~d}$. In consequence, the collected dusts are in the lower-scale limit of documented dust particles (regarding both concentration [Jickels and Spokes, 2001] and MSD (C. Zender, Particle size distributions: Theory and application to aerosols, clouds, and soils, 2007, available at http://dust.ess.uci.edu/facts/)).

\subsection{Dust/Iron Fluxes to the Southern Hemisphere Ocean}

[31] Dust fluxes calculated in this study are based on samples collected on a small timescale (i.e., duration of the cruises: 1-2 months). This timescale could be too short to integrate sporadic but important inputs of dust. However, several evidences support the representativeness of the calculated dust fluxes. During the 2 years of the OMI data series analyzed, no dust plume is observed over both studied areas, but it has to be pointed out that detection of small dust events could be problematic with OMI in the Southern Ocean [Gasso and Stein, 2007]. However, back trajectories of air masses during the time period of the OMI study also demonstrate that the probability of occurrence of a dust event is extremely low because favorable atmospheric transport does not occur. In the SEPS area, the OMI series illustrate that seasonal variations are very low with a small maximum in austral spring. This trend is confirmed by the in situ time series data collected during the SEAREX 

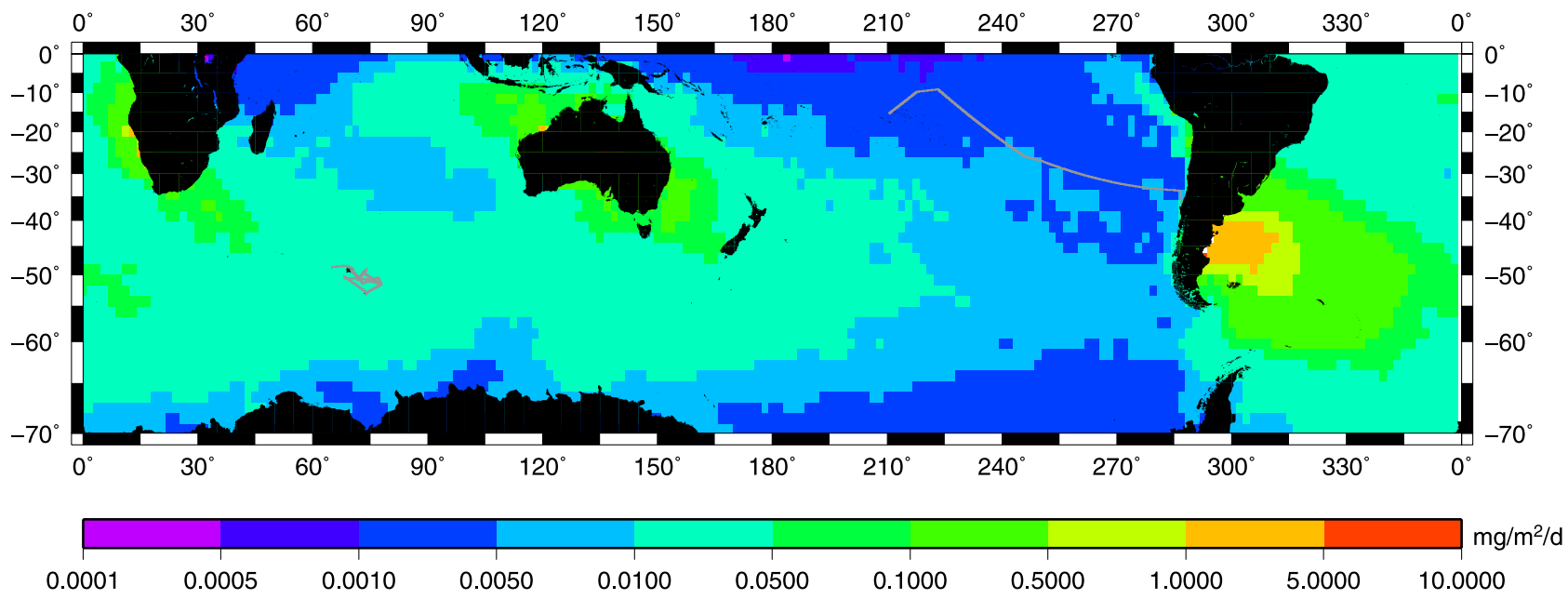

Figure 6. Average dust deposition between April 2004 and March 2005 over the Southern Hemisphere. Estimated from Lm and modified to fit the surface concentrations measured during the cruise. The cruise tracks are in gray.

program on the Samoa and Rarotonga sites [Prospero et al., 1989]. The frequency of Australian dust storms reaches also a maximum during the austral spring [McTainsh and Lynch, 1996; Mackie et al., 2008]. In the SOKS area, the OMI series is insufficient to assess seasonal variations, because of inherent problems of the A.I. (see section 2). According to the latitude of the SOKS area, this zone receives mainly dust from South American sources which are shown to have their maximum activity during austral summer months [Gaiero et al., 2003]. The precipitation values used to estimate dust deposition are not significantly different from mean values over the period (1979-2005) of the GPCP series. The wet deposition estimates are based on scavenging ratios of dust particles concentration at sea level. A mutual dependence between dry and wet values is inherent to this method and could lead to underestimation of the wet flux because particle concentrations at higher altitudes are not taken into account. Furthermore, seasonal dust deposition variations estimated by climatology from dust models are low in both SEPS and SOKS areas. In consequence, the fluxes proposed here appear to be representative values of longer-term averages. However, for both SEPS and SOKS areas, the sampling was performed during the suspected "high" dust season. Our fluxes could thus tend to slightly overestimate the annual average fluxes.

[32] In oceanic biogeochemical models which include iron as a micro nutrient, two types of data sets are used for the estimation of dust deposition: (1) fluxes estimated from dust models [see, e.g., Aumont and Bopp, 2006] and (2) fluxes estimated from dust deposition maps (as the one proposed in 1991 by Duce et al. [1991]) and based on the extrapolation of field data.

[33] Compared to our field data, the dust model overestimates dust deposition by a factor of 10 in the Southern Ocean and by a factor of 30-50 in the southeast Pacific (Table 3). One should bear in mind that there is an important difference in precipitation between the western part and the eastern part of the SEPS area (spatial distribution of precipitation is given in auxiliary material (Figure S1)), which could play on the importance of the wet deposition estimated. However, when using the highest values of precipitation in the western SEPS area from GPCP with a SR of 750 , the wet deposition flux would represent $85 \%$ of the total flux, which would still be 15 times lower than predicted by the model.

[34] The fluxes extrapolated from Duce et al. [1991] overestimate from 1 to 12 times our fluxes in the Southern Ocean and from 3 to 30 times in the southeast Pacific (Table 3). This difference between both dust estimations (model and "map") has been proposed as an important incertitude in former studies of the iron cycle in the Southern Ocean [Ridgwell and Watson, 2002]. The present study shows that for these low dust deposition areas, previously unexplored in regard to atmospheric concentrations, the older estimations based on extrapolation of field data seem to better represent the low-dust areas than dust models. The overestimation of dust fluxes by models in the Southern Hemisphere [Intergovernmental Panel on Climate Change (IPCC), 2001; Luo et al., 2003; Mackie et al., 2008] is clearly confirmed by our calculations in remote oceanic areas of this hemisphere.

[35] Figure 6 shows dust fluxes calculated as the sum of Lm estimated export of dust from the three sources corrected as described in the methods. Australian sources are multiplied by a factor 0.0159 , South American sources are multiplied by a factor 0.0400 , and South African sources are multiplied by a factor 0.0770 . In Table 5 , in situ values from the literature are compared with $\mathrm{Lm}$ values before and after source correction. A few important points have to be made concerning this new estimation of dust deposition:

[36] 1. The Northern Hemisphere sources are not taken into account. Over the largest part of the Southern Hemisphere, these sources are insignificant, but intrusion of northern dust in the Southern Hemisphere has been demonstrated in situ [Krishnamurti et al., 1998] and with models [Luo et al., 2003], which could lead to higher values than estimated in the northern latitudes. 
Table 5. Comparison Between In Situ Values of the Literature, Model Values (Lm), and Model Values With the Correction (Lm-Cor) Described in This Study (Figure 6)

\begin{tabular}{|c|c|c|c|c|c|c|}
\hline Area & Position $^{\mathrm{a}}$, Lat-Lon & Reference In Situ & Parameter $^{\mathrm{b}}$ & In Situ & $\mathrm{Lm}$ & Lm-Cor \\
\hline Tasman Sea & $40^{\circ} \mathrm{S}$ to $168^{\circ} \mathrm{E}$ & Hesse [1994] & DEP & 2.7 & 2.6 & 0.05 \\
\hline Tasman Sea & $25^{\circ} \mathrm{S}$ to $162^{\circ} \mathrm{E}$ & Kawahata [2002] & DEP & 0.8 & 1.7 & 0.03 \\
\hline Tasman Sea & $30^{\circ} \mathrm{S}$ to $162^{\circ} \mathrm{E}$ & Kawahata [2002] & DEP & 1.6 & 4.3 & 0.07 \\
\hline Tasman Sea & $35^{\circ} \mathrm{S}$ to $162^{\circ} \mathrm{E}$ & Kawahata [2002] & DEP & 5.0 & 4.6 & 0.08 \\
\hline Tasman Sea & $35^{\circ} \mathrm{S}$ to $160^{\circ} \mathrm{E}$ & Kawahata [2002] & DEP & 8.2 & 5.5 & 0.09 \\
\hline New Zealand & $45^{\circ} \mathrm{S}$ to $168^{\circ} \mathrm{E}$ & Halstead et al. [2000] & DEP & 0.8 & 1.4 & 0.03 \\
\hline Southwest Atlantic ${ }^{c}$ & $\begin{array}{l}16^{\circ} \mathrm{S} \text { to } 334^{\circ} \mathrm{E} \\
31^{\circ} \mathrm{S} \text { to } 312^{\circ} \mathrm{E}\end{array}$ & Baker et al. [2006] & $\mathrm{CONC}$ & 133 & 414 & 26.6 \\
\hline Southwest Atlantic ${ }^{\mathrm{d}}$ & $\begin{array}{l}31^{\circ} \mathrm{S} \text { to } 312^{\circ} \mathrm{E} \\
51^{\circ} \mathrm{S} \text { to } 304^{\circ} \mathrm{E}\end{array}$ & Baker et al. [2006] & CONC & 450 & 6124 & 468 \\
\hline Southwest Atlantic ${ }^{\mathrm{e}}$ & $\begin{array}{l}40^{\circ} \mathrm{S} \text { to } 305^{\circ} \mathrm{E} \\
48^{\circ} \mathrm{S} \text { to } 305^{\circ} \mathrm{E}\end{array}$ & Bowie et al. [2002] & DEP & $3.6-10$ & 17.8 & 1.4 \\
\hline Weddell Sea $^{\mathrm{e}}$ & $\begin{array}{l}63^{\circ} \mathrm{S} \text { to } 319^{\circ} \mathrm{E} \\
64^{\circ} \mathrm{S} \text { to } 306^{\circ} \mathrm{E}\end{array}$ & Sañudo-Wilhelmy et al. [2002] & DEP & $0.2-1.8$ & 0.4 & 0.03 \\
\hline South Indian Ocean ${ }^{\mathrm{e}}$ & $50^{\circ} \mathrm{S}$ to $58^{\circ} \mathrm{E}$ & Van Beusekom et al. [1997] & DEP & $0.09-0.3$ & 0.7 & 0.04 \\
\hline Amsterdam Island & $38^{\circ} \mathrm{S}$ to $72^{\circ} \mathrm{E}$ & Ezat and Dulac [1995] & $\mathrm{CONC}$ & 120 & 167 & 9.3 \\
\hline Raratonga & $21^{\circ} \mathrm{S}$ to $200^{\circ} \mathrm{E}$ & Prospero et al. [1989] & $\mathrm{CONC}$ & 110 & 149 & 3.3 \\
\hline American Samoa & $14^{\circ} \mathrm{S}$ to $191^{\circ} \mathrm{E}$ & Prospero et al. [1989] & $\mathrm{CONC}$ & 20 & 84 & 1.5 \\
\hline
\end{tabular}

${ }^{\text {a }}$ Position used for the comparison. For cruise tracks, a square area surrounding the track is defined.

${ }^{b}$ Parameter compared: CONC is dust concentration in $\mathrm{ng} \mathrm{m}^{-3}$ and DEP is dust deposition in $\mathrm{mg} \mathrm{m}^{-2} \mathrm{~d}^{-1}$.

${ }^{\mathrm{c}}$ Mean of samples $\mathrm{m} 18$ to $\mathrm{m} 22$, dust concentration is derived from $\mathrm{Al}$ concentration.

${ }^{\mathrm{d}}$ Mean of samples $\mathrm{m} 23$ to $\mathrm{m} 26$, dust concentration is derived from $\mathrm{Al}$ concentration.

${ }^{\mathrm{e}} \mathrm{Al}$ values converted to dust deposition following MADCOW [Measures and Vink, 2000].

[37] 2. The Australian source has been highly reduced to fit the SEPS data. The new estimation underestimates in situ measurements closer to Australian dust sources than SEPS area (see Tasman Sea, Rarotonga, and American Samoa data in Table 5). This suggests that overestimation of SEPS dust deposition by Lm is not derived from poor estimates of the source but may certainly result from the modeling of dust transport to SEPS area. In fact, SEPS area is not on an important route of dust export from Australia (Table 4), and even if dust would be transported from Australia in direction of SEPS area, the presence of the South Pacific convergence zone, characterized by a belt of precipitation (see auxiliary material (Figure S1)) would play a role of barrier for dust transport.

[38] 3. The South African source is badly constrained with our data, because both studied areas are very slightly impacted by this source.

[39] 4. The new estimation of dust deposition to the Southern Hemisphere presents a good to mitigate agreement with other in situ values in the South Atlantic Ocean (Table 5). As the Lm values are all overestimated for this area, this reinforces the idea that South American sources are overestimated in Lm. Because of the importance of this source for dust deposition on large areas of the Southern Ocean, this correction could have important consequences.

[40] In summary, even if one should bear in mind that Figure 6 cannot be seen as a "ready to use" product, because of the small data set incorporated, it is a valuable approach to understand global dust deposition over the Southern Hemisphere.

\subsection{Consequence upon Biogeochemistry of the Studied Areas}

[41] The respective importance of iron from below (vertical supply from the deep ocean) and above (atmospheric flux) is a key question in order to improve our knowledge of iron biogeochemistry, in particular for HNLC areas [see, e.g., Boyd et al., 2005]. In the estimation of atmospheric dissolved iron (DFe) fluxes, solubility of atmospheric iron in seawater is a major source of uncertainty [Jickells and Spokes, 2001]. Values smaller than 1\% have been observed for dust end-members [Bonnet and Guieu, 2004], whereas values of $10 \%$ have been suggested more recently for areas remote from dust sources [Baker and Jickells, 2006]. Here, solubility is assumed to range between 1 and $10 \%$. In consequence, the atmospheric fluxes of dissolved iron range between 0.2 and $3.2 \mathrm{nmol} \mathrm{m} \mathrm{m}^{-2} \mathrm{~d}^{-1}$ for SOKS area and between 0.04 and $0.8 \mathrm{nmol} \mathrm{m}^{-2} \mathrm{~d}^{-1}$ for SEPS area.

[42] During the KEOPS cruise, a massive 3 months bloom induced by natural iron fertilization was fueled by "iron from below" [Blain et al., 2007]. Within the area of natural fertilization, the diffusive vertical supply of iron was $31 \pm 21 \mathrm{nmol} \mathrm{m}^{-2} \mathrm{~d}^{-1}$ (uncertainty estimated from $\mathrm{K}_{\mathrm{z}}$ ). Outside this area, in the HNLC Southern Ocean, vertical supply of iron was $4 \mathrm{nmol} \mathrm{m} \mathrm{m}^{-2}$. This last value is comparable to other estimates in the HNLC Southern Ocean: $6.3 \mathrm{nmol} \mathrm{m}^{-2} \mathrm{~d}^{-1}$ [Bowie et al., 2001], $3 \mathrm{nmol} \mathrm{m}^{-2}$ $\mathrm{d}^{-1}$ [Law et al., 2003], $4.1 \mathrm{nmol} \mathrm{m} \mathrm{m}^{-2} \mathrm{~d}^{-1}$ [Croot et al., 2004], and between 10.5 and $21 \mathrm{nmol} \mathrm{m}^{-2} \mathrm{~d}^{-1}$ [Croot et al., 2007]. On the basis of all these values, a vertical supply of iron of $5.6 \pm 3.0 \mathrm{nmol} \mathrm{m}^{-2} \mathrm{~d}^{-1}$ for the HNLC Southern Ocean is assumed. According to our calculation, the atmospheric DFe flux represents only between $0.4 \%$ and $16 \%$ of the iron input from below in the natural fertilization area and between 3 and $78 \%$ outside this area. Thus, atmospheric dust deposition to the Southern Ocean would not have triggered the large Kerguelen bloom observed. Moreover, in the HNLC area, iron from below dominates the iron input. In the modern ocean, the dominance of iron from below by eddy diffusivity has been suggested in sectors of 
the Southern Ocean [de Baar et al., 1995] and even at the scale of the entire Southern Ocean [Watson, 2001]. A recent study based on remote sensing data analysis in the Atlantic sector of the Southern Ocean argues a control of the biological activity by upwelled iron-rich waters [Meskhidze et al., 2007]. Our data, based on in situ measurements give robust support to this assumption for the HNLC Southern Ocean. The impact of atmospheric deposition on the Southern Ocean productivity is a highly discussed point in particular on the timescale of glacial-interglacial changes [see, e.g., Martin, 1990a; Watson et al., 2000]. Recent studies have investigated the relationship between dust deposition (from models) and marine productivity and some evidences (but not unequivocally) of coupling were pointed out for the whole Southern Ocean [Cassar et al., 2007] and for specific areas close to Australian [Boyd et al., 2004; Gabric et al., 2002] or South American dust sources [Erickson et al., 2003]. For open ocean areas far from dust sources like SOKS area, where dust inputs are not dominating the iron inputs and where the probability of occurrence of a large dust event is low, the demonstration of this coupling is certainly even more difficult.

[43] One of the main areas of interest of the BIOSOPE cruise was the South Pacific gyre, the most oligotrophic region of the world ocean [Claustre et al., 2008]. South Pacific is largely unexplored and data are scarce. Since the BIOSOPE cruise, vertical distribution of iron has been measured, and profiles show low and uniform dissolved iron concentrations [Blain et al., 2008]. No diffusive supply could thus be inferred from those data to get compared with atmospheric deposition, but the supply of iron from below is likely to be also very low for this area [Blain et al., 2008]. This singularity makes this gyre unique compared to the North Pacific and Atlantic gyres, where atmospheric inputs have been shown to dominate the iron budget [Brown et al., 2005; Jickells, 1999]. In the South Pacific gyre, the primary productivity is primarily controlled by nitrogen and not by DFe availability. Furthermore nitrogen fixation rates measured in this area are extremely reduced and not stimulated by iron additions [Bonnet et al., 2008]. These recent findings are not in agreement with recent oceanic biogeochemical models claiming that nitrogen fixation is driven by iron availability in this area [Moore et al., 2004; Aumont and Bopp, 2006]. This discrepancy could be due to the overestimation of atmospheric iron fluxes by models demonstrated in this study.

\section{Conclusion}

[44] The generally accepted idea that atmospheric deposition is the main source of iron to the open ocean [Duce and Tindale, 1991; Duce et al., 1991; Fung et al., 2000] needs to be critically reevaluated for large areas of the Southern Hemisphere. The overestimation by current dust models raises interesting perspectives for the Southern Hemisphere open ocean:

[45] According to several models [e.g., Mahowald et al., 1999], dust deposition in the studied areas was 10-50 times higher during the last glacial maximum (LGM) compared to present time. This difference is of the same order of magnitude as the one observed between our in situ observations and current dust models. Furthermore, Latimer and Filippelli [2001] suggest that upwelled iron flux was higher during glacial periods. Dust models should thus be intensely compared with in situ data from a broader range of environments in order to accurately predict differences between present and past dust impact.

[46] The uncertainty on solubility processes is often proposed as the major source of incertitude in determining atmospheric DFe fluxes [see, e.g., de Baar et al., 2005]. Even if we totally agree on that point, this study shows that the determination of the dust fluxes is the first cause of uncertainty in determining atmospheric DFe fluxes.

[47] Acknowledgments. We thank the crew and officers of the French R/Vs Atalante and Marion Dufresnes. We acknowledge Michel Maillé for technical assistance with TEM and Fabrizio D'Ortenzio for his help in data handling. Francois Dulac and Stéphane Blain are acknowledged for their comments. Charlie Zender and one anonymous reviewer are deeply acknowledged for insightful comments on the manuscript. This work was supported by the Institut National des Sciences de l'Univers (INSU) du Centre National de la Recherche Scientifique (CNRS). The NASA-Goddard Space Flight Centre, Ozone Processing Team, provided daily data of OMI Aerosol Index. The NOAA Air Resource Laboratory (ARL) provided the HYSPLIT model. A BDI grant of the Region Provence-Alpes-Cote d'Azur and CNRS supported T.W.

\section{References}

Adler, R. F., et al. (2003), The version-2 global precipitation climatology project (GPCP) monthly precipitation analysis (1979-present), J. Hydrometeorol., 4, 1147-1167.

Andreae, M., R. Charlson, F. Bruynseels, and R. M. W. Storms (1986), Internal mixture of sea salt, Silicates, and excess sulfate in marine aerosols, Science, 232, 1620-1623.

Aumont, O., and L. Bopp (2006), Globalizing results from ocean in situ iron fertilization studies, Global Biogeochem. Cycles, 20, GB2017, doi:10.1029/2005GB002591.

Baker, A. R., and T. D. Jickells (2006), Mineral particle size as a control on aerosol iron solubility, Geophys. Res. Lett., 33, L17608, doi:10.1029/ 2006GL026557.

Baker, A. R., T. D. Jickells, M. Witt, and K. L. Linge (2006), Trends in the solubility of iron, aluminium, manganese and phosphorus in aerosol collected over the Atlantic Ocean, Mar. Chem., 98, 43-58.

Betzer, P., et al. (1988), Long-range transport of giant mineral aerosol particles, Nature, 336, 568-571.

Blain, S., et al. (2007), Effect of natural iron fertilization on carbon sequestration in the Southern Ocean, Nature, 446, doi:10.1038/ nature 05700 .

Blain, S., S. Bonnet, and C. Guieu (2008), Dissolved iron distribution in the tropical and sub tropical south eastern Pacific, Biogeosciences, 5, 269280 .

Bonnet, S., and C. Guieu (2004), Dissolution of atmospheric iron in seawater, Geophys. Res. Lett., 31, L03303, doi:10.1029/2003GL018423.

Bonnet, S., et al. (2008), Nutrients limitation of primary productivity in the southeast Pacific (BIOSOPE cruise), Biogeosciences, 5, 215-225.

Bowie, A. R., et al. (2001), The fate of added iron during a mesoscale fertilisation experiment in the Southern Ocean, Deep Sea Res., Part II, $48,2703-2743$

Bowie, A. R., D. J. Whitworth, E. P. Achterberg, R. F. C Mantoura, and P. J. Worsfold (2002), Biogeochemistry of Fe and other trace elements (Al, Co, Ni) in the upper Atlantic Ocean, Deep Sea Res., Part II, 49, 605-636.

Boyd, P. W., et al. (2004), Episodic enhancement of phytoplankton stocks in New Zealand Subantarctic waters: Contribution of atmospheric and oceanic iron supply, Global Biogeochem. Cycles, 18, GB1029, doi:10.1029/2002GB002020.

Boyd, P. W., et al. (2005), FeCycle: Attempting an iron biogeochemical budget from a mesoscale SF6 tracer experiment in unperturbed low iron waters, Global Biogeochem. Cycles, 19, GB4S20, doi:10.1029/ 2005 GB002494.

Boyd, P. W., et al. (2007), Mesoscale iron enrichment experiments $1993-$ 2005: Synthesis and future directions, Science, 315, 612-617.

Brown, M. T., W. M. Landing, and C. I. Measures (2005), Dissolved and particulate Fe in the western and central North Pacific: Results from the 
2002 IOC cruise, Geochem. Geophys. Geosyst., 6, Q10001, doi:10.1029/ 2004GC000893.

Buat-Menard, P., and R. A. Duce (1986), Precipitation scavenging of aerosol particles over remote marine regions, Nature, 321, 508-510.

Cassar, N., M. L. Bender, B. A. Barnett, S. Fan, W. J. Moxim, I. Levy, and B. Tilbrook (2007), The Southern Ocean biological response to aeolian iron deposition, Science, 317, 1067-1070.

Claustre, H., A. Sciandra, and D. Vaulot (2008), Introduction to the specia section: Biooptical and biogeochemical conditions in the south eas Pacific in late 2004: The BIOSOPE Cruise, Biogeosci. Disc., 5, $605-$ 640.

Croot, P. L., K. Andersson, M. Öztürk, and D. Turner (2004), The distribution and speciation of iron along $6^{\circ} \mathrm{E}$, in the Southern Ocean, Deep Sea Res., Part II, 51, 2857-2879.

Croot, P. L., et al. (2007), Physical mixing effects on iron biogeochemical cycling: FeCycle experiment, J. Geophys. Res., 112, C06015, doi:10.1029/2006JC003748.

de Baar, H. J. W., J. T. M. de Jong, D. C. E. Bakker, B. M. Loscher, C. Veth, U. Bathmann, and V. Smetacek (1995), Importance of iron for plankton blooms and carbon dioxide drawdown in the Southern Ocean, Nature, 373(6513), 412-415.

de Baar, H. J. W., et al. (2005), Synthesis of iron fertilization experiments: From the iron age in the age of enlightenment, J. Geophys. Res., 110, C09S16, doi:10.1029/2004JC002601.

Dell'Aquila, A., P. M. Ruti, S. Calmanti, and V. Lucarini (2007), Southern Hemisphere midlatitude atmospheric variability of the NCEP-NCAR and ECMWF reanalyses, J. Geophys. Res., 112, D08106, doi:10.1029/ 2006JD007376.

Dick, A. (1991), Concentrations and sources of metals in the Antarctic peninsula aerosol, Geochim. Cosmochim. Acta, 55, 1827-1836.

Draxler, R., and G. Rolph (2003), Hybrid Single-Particle Langrangian Integrated Trajectory (HYSPLIT) model access via NOAA ARL READY Web site, technical report, NOAA Air Resources Laboratory, Silver Spring, Md. (Available at http://www.arl.noaa.gov/ready/hysplit4.html)

Duce, R. (1989), SEAREX: The Sea-Air Exchange Program, in Chemical Oceanography, vol. 10, edited by R. Chester, chap. 52, pp. 1-14, Elsevier, New York.

Duce, R., and N. Tindale (1991), Atmospheric transport of iron and its deposition in the ocean, Limnol. Oceanogr., 36, 1715-1726.

Duce, R., et al. (1991), The atmospheric input of trace species to the world ocean, Global Biogeochem. Cycles, 5, 193-259.

Dulac, F., P. Buat-Ménard, U. Ezat, S. Melki, and G. Bergametti (1989), Atmospheric input of trace metals to the western Mediterranean: Uncertainties in modelling dry deposition from cascade impactor data, Tellus, Ser. $B, 41,362-378$.

Dulac, F., R. Losno, G. Bergametti, S. Triquet, T. Wagener, C. Guieu, and M. Lebouvier (2006), Is Kerguelen's desert a significant source of dissolved iron to the downwind surface ocean?, Eos Trans. AGU, 87(36), Ocean Sci. Meet. Suppl., Abstract OS35M-21.

Erickson, D. J., et al. (2003), Atmospheric iron delivery and surface ocean biological activity in the Southern Ocean and Patagonian region, Geophys. Res. Lett., 30(12), 1609, doi:10.1029/2003GL017241.

Ezat, U., and F. Dulac (1995), Size distribution of mineral aerosols at Amsterdam Island and dry deposition rates in the southern Indian Ocean, C.R. Acad. Sci., Ser. II, 320, 9-14.

Fung, I. Y., S. K. Meyn, I. Tegen, S. C. Doney, J. G. John, and J. K. B. Bishop (2000), Iron supply and demand in the upper ocean, Global Biogeochem. Cycles, 14, 282-295.

Gabric, A. J., R. Cropp, G. P. Ayers, G. McTainsh, and R. Braddock (2002) Coupling between cycles of phytoplankton biomass and aerosol optical depth as derived from SeaWiFS time series in the Subantarctic Southern Ocean, Geophys. Res. Lett., 29(7), 1112, doi:10.1029/2001GL013545.

Gaiero, D. M., J. L. Probst, P. J. Depetris, S. M. Bidart, and L. Leleyter (2003), Iron and other transition metals in Patagonian riverborne and windborne materials: Geochemical control and transport to the southern South Atlantic Ocean, Geochim. Cosmochim. Acta, 67, 3603-3623.

Gasso, S., and A. F. Stein (2007), Does dust from Patagonia reach the subAntarctic Atlantic Ocean?, Geophys. Res. Lett., 34, L01801, doi:10.1029/ 2006GL027693.

Gaudichet, A., J. Petit, R. Lefevre, and C. Lorius (1986), An investigation by analytical transmission electron microscopy of individual insoluble microparticle from Antarctic (Dome C) ice core samples, Tellus, Ser. B, $38,250-261$

Ginoux, P., and O. Torres (2003), Empirical TOMS index for dust aerosol: Applications to model validation and source characterization, J. Geophys. Res., 108(D17), 4534, doi:10.1029/2003JD003470.

Ginoux, P., J. M. Prospero, O. Torres, and M. Chin (2004), Long-term simulation of global dust distribution with the GOCART model: Correla- tion with North Atlantic Oscillation, Environ. Modell. Software, 19, $113-$ 128

Global Precipitation Climatology Project (GPCP) (2000), GPCP Version 2 Combined Precipitation Data Set, World Data Cent. for Meteorol., Asheville, N.C. (Available at http://www.ncdc.noaa.gov/oa/wmo/wdcametncdc.html)

Halstead, M. J. R., R. G. Cunninghame, and K. A. Hunter (2000), Wet deposition of trace metals to a remote site in Fiordland, New Zealand, Atmos. Environ., 34, 665-676.

Hand, J., N. Mahowald, Y. Chen, R. Siefert, C. Luo, A. Subramaniam, and I. Fung (2004), Estimates of soluble iron from observations and a global mineral aerosol model: Biogeochemical implications, J. Geophys. Res., 109, D17205, doi:10.1029/2004JD004574.

Herman, J. R., P. K Bhartia, O. Torres, C. Hsu, C. Seftor, and E. Celarier (1997), Global distribution of UV-absorbing aerosols from Nimbus 7/ TOMS data, J. Geophys. Res., 102(D14), 16,911-16,922.

Hesse, P. P. (1994), The record of continental dust from Australia in Tasman Sea sediments, Ouat. Sci. Rev., 13(3), 257-272.

Intergovernmnetal Panel on Climate Change (IPCC) (2001), Aerosols, their direct and indirect effects, in Climate Change 2001, The Scientific Basis, edited by the Intergovernmental Panel on Climate Change, chap. 5, pp. 239-287, Cambridge Univ. Press, Cambridge, UK.

Jickells, T. D. (1999), The inputs of dust derived elements to the Sargasso Sea: A synthesis, Mar. Chem., 68, 5-14.

Jickells, T. D., and L. Spokes (2001), Atmospheric iron inputs to the ocean, in The Biogeochemistry of Iron in Seawater, edited by D. A. Turner and K. A. Hunter and Hunter, pp. 85-121, John Wiley, Hoboken, N.J.

Jickells, T. D., et al. (2005), Global iron connections between desert dust, ocean biogeochemistry, and climate, Science, 308, 67-71.

Kawahata, H. (2002), Shifts in oceanic and atmospheric boundaries in the Tasman Sea (southwest Pacific) during the late Pleistocene: Evidence from organic carbon and lithogenic fluxes, Palaeogeogr. Palaeoclimatol. Palaeoecol., 184, 225-249.

Kistler, R., et al. (2001), The NCEP-NCAR 50-year reanalysis: Monthly means CD-ROM and documentation, Bull. Am. Meteorol. Soc., 82, $247-267$

Krishnamurti, T. N., B. Jha, J. Prospero, A. Jayaraman, and V. Ramanathan (1998), Aerosol and pollutant transport and their impact on radiative forcing over the tropical Indian Ocean during the January-February 1996 pre-INDOEX cruise, Tellus, Ser. B, 50, 521-542.

Latimer, J. C., and G. M. Filippelli (2001), Terrigenous input and paleoproductivity in the Southern Ocean, Paleoceanography, 16, 627-643.

Law, C. S., E. R. Abraham, A. J. Watson, and M. I. Liddicoat (2003), Vertical eddy diffusion and nutrient supply to the surface mixed layer of the Antarctic Circumpolar Current, J. Geophys. Res., 108(C8), 3272, doi:10.1029/2002JC001604.

Luo, C., N. M. Mahowald, and J. del Corral (2003), Sensitivity study of meteorological parameters on mineral aerosol mobilization, transport, and distribution, J. Geophys. Res., 108(D15), 4447, doi:10.1029/2003JD003483.

Luo, C., N. Mahowald, N. Meskihidze, Y. Chen, R. Siefert, A. Baker, and A. Johansen (2005), Estimation of iron solubility from observations and a global aerosol model, J. Geophys. Res., 110, D23307, doi:10.1029/ 2005JD006059.

Mackie, D. S., P. W. Boyd, G. H. McTainsh, N. W. Tindale, T. K Westberry, and K. A. Hunter (2008), Biogeochemistry of iron in Australian dust: From eolian uplift to marine uptake, Geochem. Geophys. Geosyst., 9, Q03Q08, doi:10.1029/2007GC001813.

Mahowald, N. M., P. J. Rasch, B. E. Eaton, S. Whittlestone, and 151. Prinn (1997), Transport of ${ }^{222}$ radon to the remote troposphere using the Model of Atmospheric Transport and Chemistry and assimilated winds from ECMWF and the National Center for Environmental Prediction/NCAR, J. Geophys. Res., 102(D23), 28,139-28,151

Mahowald, N., K. Kohfeld, M. Hansson, Y. Balkanski, S. P. Harrison, I. C. Prentice, M. Schulz, and H. Rodhe (1999), Dust sources and deposition during the last glacial maximum and current climate: A comparison of model results with paleodata from ice cores and marine sediments, J. Geophys. Res., 104(D13), 15,895-15,916.

Mahowald, N., C. Zender, C. Luo, J. D. Corral, D. Savoie, and O. Torres (2002), Understanding the 30-year Barbados desert dust record, J. Geophys. Res., 107(D21), 4561, doi:10.1029/2002JD002097.

Mahowald, N., C. Luo, J. D. Corral, and C. Zender (2003), Interannual variability in atmospheric mineral aerosols from a 22-year model simulation and observational data, J. Geophys. Res., 108(D12), 4352 , doi:10.1029/2002JD002821.

Mahowald, N., G. Bergametti, N. Brooks, R. Duce, T. D. Jickells, N. Kubilay, J. Prospero, and I. Tegen (2005), Atmospheric global dust cycle and iron inputs to the ocean, Global Biogeochem. Cycles, 19, GB4025, doi:10.1029/2004GB002402. 
Maring, H., D. L. Savoie, M. A. Izaguirre, L. Custals, and J. S. Reid (2003), Mineral dust aerosol size distribution change during atmospheric transport, J. Geophys. Res., 108(D19), 8592, doi:10.1029/2002JD002536.

Martin, J. (1990), Glacial-interglacial $\mathrm{CO}_{2}$ change: The iron hypothesis, Paleoceanography, 5, 1-13.

Martin, J., and S. Fitzwater (1988), Iron deficiency limits phytoplankton growth in the north-east Pacific Subarctic, Nature, 331, 341-343.

McTainsh, G. H., and A. W. Lynch (1996), Quantitative estimates of the effect of climate change on dust storm activity in Australia during the Last Glacial Maximum, Geomorpholgy, 17, 263-271.

Measures, C. I., and S. Vink (2000), On the use of dissolved aluminium in surface waters to estimate dust deposition to the ocean, Global Biogeochem. Cycles, 14, 317-327.

Merrill, J. (1989), Atmospheric long-range transport to the Pacific Ocean, in Chemical Oceanography, vol. 10, edited by J. P. Riley and R. Chester, pp. 15-49, Elsevier, New York.

Meskhidze, N., A. Nenes, W. L. Chameides, C. Luo, and N. Mahowald (2007), Atlantic Southern Ocean productivity: Fertilization from above or below?, Global Biogeochem. Cycles, 21, GB2006, doi:10.1029/ 2006GB002711.

Mills, M. M., C. Ridame, M. Davey, J. La Roche, and R. J. Geider (2004), Iron and phosphorus co-limit nitrogen fixation in the eastern tropical North Atlantic, Nature, 429, 292-294.

Moore, J. K., S. C. Doney, and K. Lindsay (2004), Upper ocean ecosystem dynamics and iron cycling in a global three-dimensional model, Global Biogeochem. Cycles, 18, GB4028, doi:10.1029/2004GB002220.

Parekh, P., M. J. Follows, S. Dutkiewicz, and T. Ito (2006), Physical and biological regulation of the soft tissue carbon pump, Paleoceanography, 21, PA3001, doi:10.1029/2005PA001258.

Prospero, J., M. Uematsu, and D. Savoie (1989), Mineral Aerosol transport to the Pacific Ocean, in Chemical Oceanography, vol. 10, edited by J. P. Riley and R. Chester, pp. 188-216, Elsevier, New York.

Prospero, J. M., P. Ginoux, O. Torres, S. E. Nicholson, and T. E. Gill (2002), Environmental characterization of global sources of atmospheric soil dust identified with the Nimbus 7 Total Ozone Mapping Spectrometer (TOMS) absorbing aerosol product, Rev. Geophys., 40(1), 1002, doi:10.1029/2000RG000095.

Ridgwell, A. J., and A. J. Watson (2002), Feedback between aeolian dust, climate, and atmospheric $\mathrm{CO}_{2}$ in glacial time, Paleoceanography, 17(4), 1059, doi:10.1029/2001PA000729.
Sañudo-Wilhelmy, S. A., K. A. Olsen, J. M. Scelfo, T. D. Foster, and A. R. Flegal (2002), Trace metal distributions off the Antarctic Peninsula in the Weddell Sea, Mar. Chem., 77, 157-170.

Slinn, S. A., and W. Slinn (1980), Predictions for particle deposition on natural waters, Atmos. Environ., 14, 1013-1016.

Tanaka, T. Y., and M. Chiba (2006), A numerical study of the contributions of dust source regions to the global dust budget, Global Planet. Change, 52, $88-104$.

Tegen, I., S. P. Harrison, K. Kohfeld, I. C. Prentice, M. Coe, and M. Heimann (2002), Impact of vegetation and preferential source areas on global dust aerosol: Results from a model study, J. Geophys. Res., 107(D21), 4576, doi:10.1029/2001JD000963.

Van Beusekom, J. E. E., A. J. Van Bennekom, P. Treguer, and J. Morvan (1997), Aluminium and silicic acid in water and sediments of the Enderby and Crozet basins, Deep Sea Res., Part II, 44, 987-1003.

Watson, A. (2001), Iron limitations in the oceans, in The Biogeochemistry of Iron in Seawater, edited by D.A. Turner and K. A. Hunter, chap. 2, pp. 940, John Wiley, Hoboken, N.J.

Watson, A., D. Bakker, A. Ridgwell, P. Boyd, and C. Law (2000), Effect of iron supply on Southern Ocean $\mathrm{CO}_{2}$ uptake and implications for glacial atmospheric $\mathrm{CO}_{2}$, Nature, 407, 730-733.

Wedepohl, K. (1995), The composition of the continental crust, Geochim. Cosmochim. Acta, 59, 1217-1232.

Witt, M., A. Baker, and T. Jickells (2006), Atmospheric trace metals over the Atlantic and south Indian oceans: Investigation of metal concentrations and lead isotope ratios in coastal and remote marine aerosols, Atmos. Environ., 40(28), 5435-5451.

Zender, C., H. Bian, and D. Newman (2003), Mineral Dust Entrainment and Deposition (DEAD) model: Description and 1990s dust climatology, J. Geophys. Res., 108(D14), 4416, doi:10.1029/2002JD002775.

S. Bonnet, IRD, Laboratoire d'Océanographie et de Biogéochimie (L.O.B), Campus de Luminy, Case 901, 13288 Marseille, France.

C. Guieu and T. Wagener, Laboratoire d'Océanographie de Villefranche sur Mer, UMR 7093, CNRS, BP08 06238 Villefranche sur mer, France.

R. Losno, Laboratoire Interuniversitaire des Systèmes Atmosphériques, UMR 7583, CNRS, Faculté des Sciences et Technologie, 61 avenue du Général de Gaulle, 94010 Créteil Cedex, France.

N. Mahowald, National Center for Atmospheric Research, Boulder, CO 870302, USA. 